\title{
Inflation Targeting in an Open Financially Integrated Emerging Economy: The Case of Brazil
}

\author{
Marcelo Kfoury Muinhos
}

\author{
Doutor em Economia - Universidade de Cornell e \\ Pesquisador do Banco Central do Brasil
}

\section{RESUMO}

Este trabalho conduz algumas simulações da regra de Taylor ampliada (com a taxa de câmbio adicionada). Essas simulações foram feitas também para analisar choques externos em um modelo simples de Metas de Inflação com equações de balança comercial. Em contraste com Ball (2000), quando a taxa de câmbio é incluída na regra de Taylor, a volatilidade do produto aumenta após um choque negativo no fluxo de capitais. Além disso, o paper apresenta um estudo do pass-through da desvalorização da taxa de câmbio para a inflação considerando a mudança recente no regime das taxas de câmbio no Brasil. Estimativas econométricas foram feitas usando as especificações do pass-through sugeridas por Goldfajn e Werlang (2000).

\section{PALAVRAS-CHAVE}

pass-through, flutuação da taxa de câmbio, regra de Taylor

ABSTRACT

This paper conducts simulations of the augmented Taylor rule (with an added exchange rate term). It has also been made to analyze the response from external shocks in a simple Inflation Targeting model with trade balance equations. In contrast to Ball (2000), when the exchange rate is included in the Taylor rule, output volatility increases after a negative shock to the capital inflow. The paper also studies the pass-through from the exchange rate devaluation to inflation considering the recent change in the foreign exchange regime in Brazil. Econometric estimations were performed using the specifications of the pass-through suggested by Goldfajn and Werlang (2000)

KEY WORDS

pass-through, floating exchange rate, Taylor rule

JEL Classification

E44, E58, F3I, F32 


\section{INTRODUCTION}

In recent years, one can observe that an increased number of countries have adopted inflation targeting as their monetary policy regime. Even among emerging markets, this policy regime has been adopted recently in a number of countries such as Chile, Brazil, Poland, and Israel. In the opposite direction, some authors such as Calvo and Reinhart (2000) empirically conclude that emerging countries have a bias against flexible exchange rates that are an important feature of the inflation-targeting framework.

They argue that the reasons for the alleged bias against exchange-rate flexibility are in general linked to the high pass-through from the exchange rate to inflation (fear of inflation) and the financial imbalances caused by the high degree of foreign-currency indebtedness of firms in those countries (fear of floating). Ball (2000) doubts the adoption of a purely inflation-targeting framework is efficient, unless the monetary policy rule is modified in order to give some role to the exchange rate.

This paper conducts simulations in a simple inflation-targeting model for Brazil that include equations for the trade balance and an augmented Taylor rule (with an added exchange rate term) as suggested by Ball (2000). Those simulations enable us to obtain the response for external shocks. In contrast to Ball (2000), when the exchange rate is included, output volatility increases after a negative capital inflow shock.

This paper also conducts a study of the pass-through from the exchange rate devaluation to inflation considering the recent change in the foreign exchange regime in Brazil. Econometric estimations were performed using the pass-through specifications suggested by Goldfajn and Werlang (2000).

The paper is organized as follows. Section 1 presents some stylized facts regarding the alleged limited flexibility of the exchange rate in emerging markets countries. Section 2 presents the econometric estimations of the passthrough for Brazil. The following section discusses a simple model with a modified Taylor Rule and an Uncovered Interest Parity rule, which depends 
on the trade balance surplus. Section 4 shows the simulation exercises and the last section concludes the paper.

\section{STYLIZED FACTS ABOUT THE LIMITED FLEXIBILITY OF THE EXCHANGE RATE IN EMERGING COUNTRIES}

The main reasons that are usually presented as the cause of limited flexibility of exchange rate in emerging market countries are:

- the high degree of pass-through from the exchange rate to inflation;

- the financial impact of devaluations on dollar denominated liabilities in the balance sheet of firms;

- the recessionary impact of major devaluations.

In this section we discuss each of the above arguments and use them to frame the Brazilian experience with a floating exchange rate regime.

The empirical evidence on the limited flexibility of the exchange rate in emerging countries (even in those that defined themselves as free floating) has been discussed in many papers. Calvo and Reinhart (2000) is the main reference on this matter.

Regarding the pass-through, Haussmann, Panizza and Stein (1999) present a table with the estimations of the inflation pass-through for more than 40 countries. The authors estimate a below 5\% 12-months pass-through for G7 countries, and on the other extreme, countries like Mexico, Paraguai and Poland have a pass-through higher than $50 \%$.

According to Goldfajn and Werlang (2000), the reasons for the low passthrough in the Brazilian January/1999 episode are: (a) the recessionary environment in the period, that unable the firms to increase the prices after the devaluation (b) a perceived overvalued exchange rate before floating, that allows a correction in the ratio of tradable and non-tradable without a generalized increase in prices and (c) a low initial inflation in 1998. For 
these reasons, the pass-through indeed was very low in this single episode, but there is no guarantee that this will be the average pass-through for the Brazilian economy. In other phases of the business cycle and with the exchange rate closer to the equilibrium level, the pass-through might be higher. The next section presents some estimations for the pass-through in Brazil.

The second negative consequence of extreme volatility of the exchange rate in emerging markets is the occurrence of financial crises caused by the dollar denominated liabilities of firms. Haussmann, Panizza and Stein (2000) argued that:

"Central Banks of countries unable to borrow in their own currency will internalize the potential impact of a depreciation due to currency mismatches when carrying out exchange rate and monetary policy."

Those mismatches are even more dramatic in a financially integrated world, where any rumor of financial problems can generate capital flight that might produce self-fulfilling crises.

The third undesirable impact of the devaluations is the resulting recession. Calvo and Reinhart (2000) show that there is no evidence of expansionary effects of devaluation even in developed economies, anyway the drop in GDP growth is higher in emerging countries than in developed ones.

Goldfajn and Olivares (2001) also contributed to the debate about the choice of exchange regime. They gathered stylized facts as following:

"developing countries prefer to allow a higher volatility of reserves and interest rates in exchange for a lower volatility on their exchange rate. (...) Second, the sensitivity of domestic interest rates to the international interest rate is higher under fixed exchange regimes than under floating regimes. Finally, devaluation seems to be more contractionary in developing countries, but limited to currency crisis periods and in the very short run." 
They also concluded using a panel that countries more integrated to the international financial markets and with a weaker current account position are less able to use the exchange rate to respond to external shocks.

Analyzing these stylized facts in regard to the Brazilian recent floating experience, we want to show that exchange rate flexibility is not a major concern for Brazilian policymakers. However, a more careful analysis of the impact of the devaluation on the inflation rate is required including the exchange rate as a policy instrument in the monetary policy rule. The next section presents some empirical evidence of the pass-through in Brazil, and after that, a model including the exchange rate in the Taylor rule and uncovered interest parity depending upon which fundamentals are presented.

\section{PASS-THROUGH IN BRAZIL: EMPIRICAL EVIDENCE}

All the econometric estimates for the Brazilian experience in this paper are based on two equations presented in Goldfajn and Werlang (2000). Two samples were used and forward-looking terms and instrumental variables were also added to the specifications. In order to choose the best results, some in-and-out-of-sample tests were performed.

The first equation is a standard Phillips curve equation, adding a term for the real exchange rate gap and also for the degree of openness of the economy in the standard Phillips curve:

$$
\pi_{t}=\beta_{0}+\beta_{1}\left(e_{t}-e_{t-1}\right)+\beta_{2} R E R_{-1}+\beta_{3} h_{t-1}+\beta_{4} \pi_{t-1}+\beta_{5} O P E_{l-1}+u_{t}
$$

where $\pi$ is the quarterly IPCA inflation, $h$ is the output gap measured as GDP minus a linear trend, RER is the real exchange rate gap and OPE is the degree of openness of the economy. The degree of openness is the ratio of the sum of import and export to GDP. The real exchange rate gap is the percentage difference between the actual real exchange rate ${ }^{1}$ and a HodrickPrescott filter of the real exchange rate.

1 The real exchange rate is the price of one dollar in local currency deflated by domestic CPI and US PPI. 
Table 1 presents the results for the 1994:4-2002:2 period (columns (1) and (2)), considering quarterly data. A forward-looking term was also included to cover for inflation expectations in column (2). There are many alternatives for modeling expectations. The chosen alternative is to estimate a simple Arma process as the forward-looking term. ${ }^{2}$ This equation tries to be a proxy of economic agents expectations. When the forward-looking term is used, there is certainly correlation with the error term, so it is important to use instrumental variables to correct it. The estimations, by a two-stage least squared using as instrument the lagged exogenous variable, ${ }^{3}$ are presented in column (2) of Table 1.

TABLE 1 - LINEAR PHILLIPS

\begin{tabular}{|c|c|c|}
\hline Coefficients & $\begin{array}{l}\text { Short sample } \\
\text { w/o forward } / 1 \\
\text { (1) }\end{array}$ & $\begin{array}{c}\text { Short } \\
\text { w/forward } \\
\text { (2) }\end{array}$ \\
\hline Dependent variable & inf & inf \\
\hline constant & 0,01 & \\
\hline$/ 2$ & (2.53) & \\
\hline \multirow[t]{2}{*}{ pass-though } & 0,07 & 0,14 \\
\hline & (2.85) & (1.17) \\
\hline \multirow[t]{2}{*}{ RER gap } & 0,02 & 0,07 \\
\hline & $(1.17)$ & (1.84) \\
\hline \multirow[t]{2}{*}{ output gap } & 0,28 & 0,35 \\
\hline & (2.92) & (1.74) \\
\hline \multirow[t]{2}{*}{ backward inf. } & 0,51 & \\
\hline & $(5.06)$ & \\
\hline \multirow[t]{2}{*}{ forward inf. } & & 1,18 \\
\hline & & (12.18) \\
\hline$R^{2}$ & 0,73 & 0,720 \\
\hline
\end{tabular}

/1 without forward-looking term and sample from 1994:4 to 2002:2.

$/ 2 \mathrm{t}$ statistics in parentheses

2 An $\operatorname{Arma}(2,1)$ for inflation was used as a proxy for the agent's expectations.

3 The instrument list: constant, RER gap(-1), inf(-1), infarma(-1)[inflation expectiation based in an Arma process] pass-though(-1), d adm(2000:3)[dummy for administrative prices]. 
The pass-through coefficient is robust for the estimation without forwardlooking term. The contemporaneous value is around 10\% and is comparable to the Goldfajn and Werlang (2000) estimate for the 3-month passthrough. However, it is smaller than the $19.9 \%$ value for the America region and similar to the European number. The output gap coefficient is around $30 \%$ and greater than in Goldfajn and Werlang (2000) which is lower $(0.015)$. The deviation of the real exchange rate from the equilibrium value is not significant in any model. The same thing happened with the degree of openness then it was excluded from the equation in Table 1.

The second equation presented in Goldfajn and Werlang (2000) is a nonlinear equation. As explained above, the pass-through is positively related to the output gap, the initial inflation rate and the degree of openness and with the real exchange rate misalignment from its equilibrium.

$\pi_{t}=\beta_{0}+\beta_{1}\left(e_{t}-e_{t-1}\right)+\beta_{2} R E R_{t-1}+\beta_{3} h_{t-1}+\beta_{4} \pi_{t-1}+\beta_{5} O P E_{t-1}+u_{t}$ (2)

where $\quad \beta_{1}=\beta_{6}+\beta_{7} R E R_{t-1}+\beta_{8} h_{t-1}+\beta_{9} \pi_{t-1}+\beta_{10} O P E_{t-1}$

Table 2 contains the results for the non-linear equation. Column (4) contains a forward-looking term. ${ }^{4}$ In the non-linear Phillips curve, instrumental variables were the exogenous lagged variables. ${ }^{5}$ The coefficient for the initial inflation was not significant in any specification and the coefficient for the real exchange rate gap was only significant for the estimation (4). The constant terms inside the pass-through $\left(\beta_{6}\right)$ in Table 2 (columns (4) and (5)) are not comparable to the ones reported in Table 1 and they are not significant at conventional levels.

The output gap $\left(e_{t}-e_{t-1}\right)$ is significant only in (4) and in both specifications they have the expected sign. In the recession phase of the business cycle the pass-through is smaller and then the sign should have been positive. The sign and the magnitude ${ }^{6}$ of the real exchange rate gap are in line with Gol-

4 The same specification for the Arma process.

5 The instrument list: constant, RER gap(-3), inf(-1), infarma(-1) pass-though(-1), d adm $(-1,(2000: 3)),\left(\right.$ RER $^{*}\left(\right.$ e-et-1)(-3)), (output gap* ${ }^{*}$ e-et-1)(-3))

6 The value of the cross term RER* $\hat{\mathrm{E}}$ after 12 months in Goldfajn \&Werlang (2000) is 0.67 and highly significant. 
dfajn and Werlang (2000). The intuition behind this is that because exchange was overvalued pass-through is smaller, meaning room for a correction in relative prices (tradable \& non-tradable). The cross term $O P E^{*}\left(e_{t}-e_{t-1}\right)$ is not important statically in the estimations and it is excluded in (4).

TABLE 2 - NON-LINEAR PHILLIPS

\begin{tabular}{|c|c|c|}
\hline Coefficients & $\begin{array}{c}\text { Short } \\
\text { w/o for } / 1 \\
\text { (3) }\end{array}$ & $\begin{array}{c}\text { Short } \\
\text { w/ for } \\
(4)\end{array}$ \\
\hline Dependent variable & inf & inf \\
\hline constant & 0,61 & \\
\hline 12 & $(0.48)$ & \\
\hline \multirow[t]{2}{*}{ RER gap } & 1,57 & 0,06 \\
\hline & $(0.77)$ & (2.18) \\
\hline \multirow[t]{2}{*}{ output gap } & 0,41 & 0,31 \\
\hline & $(3.83)$ & (2.63) \\
\hline \multirow[t]{2}{*}{ backward inf. } & 0,45 & \\
\hline & (3.83) & \\
\hline \multirow[t]{2}{*}{ forward inf. } & & 1,29 \\
\hline & & $(13.03)$ \\
\hline \multirow[t]{2}{*}{ constant pass-through } & $-0,04$ & 0,11 \\
\hline & $(-0.80)$ & $(1.58)$ \\
\hline \multirow[t]{2}{*}{$\operatorname{RER}^{\star}\left(e-e_{t-1}\right)$} & 0,56 & 1,30 \\
\hline & (2.3) & (2.28) \\
\hline \multirow[t]{2}{*}{ output gap ${ }^{\star}(e-e t-1)$} & 0,31 & 1,30 \\
\hline & (1.03) & (2.28) \\
\hline \multirow[t]{2}{*}{ D. Adm (2000:3) } & 3,39 & - \\
\hline & (3.34) & - \\
\hline$R^{2}$ & 0,800 & 0,770 \\
\hline
\end{tabular}


Table 3 presents in-sample and out-of-sample performance tests for the four different specifications. The first two columns are the out-of-sample sum of squared errors (SQE) from 1998:1 to 2002:2. ${ }^{7}$ The first is the average of the one to four-steps ahead forecasts compared to the actual inflation outcome and the second is only the one-step ahead forecast. The out-of-sample results are robust with the forward-looking specifications getting better performance. The in-sample test the non-linear specification with forward looking term is also the best one, but the specification (3) is not the worst any more, because its in-sample forecast for 1999:1 is not that bad as the out-of-sample ones. The unique exception for out-of-sample forecast for this quarter is specification (4) the non-linear with a forward-looking term. However all models present good results for the in sample forecast in this quarter.

TABLE 3 - PERFORMANCE OF DIFFERENT SPECIFICATIONS

\begin{tabular}{|c|c|c|c|c|c|c|}
\hline \multirow[t]{2}{*}{ Models } & & SQE & SQE & SQE & Forecast & Forecast \\
\hline & & $\begin{array}{c}1 \text { to } 4 \text { periods } \\
\text { ahead }\end{array}$ & 1 period ahead & & 1999:1 & 1999:1 \\
\hline Linear & & & & & occured & 2,83 \\
\hline w/o forward & (1) & 49,6 & 40,7 & 20,3 & $-1,51$ & 1,95 \\
\hline w/ forward & (2) & 29,1 & 32,1 & 27,4 & $-0,04$ & 4,12 \\
\hline \multicolumn{7}{|l|}{ Non Linear } \\
\hline w/o forward & (3) & 1458,4 & 3235,0 & 20,6 & 59,45 & 2,39 \\
\hline w/ forward & (4) & 28,5 & 27,3 & 9,8 & 1,75 & 3,25 \\
\hline
\end{tabular}

Table 4 shows the evolution of the pass-through when the sample is expanded. ${ }^{8}$ Before 1999:1, the contemporaneous pass-through coefficient is higher than $50 \%$ for the short-sample specifications. This is the explanation for

7 The SQE test is a rolling window with a sample starting in 1994:4 and adding one more observation. In each sample is computed the squared error for the one-step ahead forecast and the average of the one to four step ahead forecasts.

8 The sample is expanded but the first observation is always 1994:4. 
the enormous out-of sample forecast. After the floating the pass-through reduces steadily for the first two columns.

TABLE 4 - PASS-THROUGH ADJUSTMENTS

\begin{tabular}{lcc}
\hline Period & $\begin{array}{c}\text { Short } \\
\text { w/o for } \\
(1)\end{array}$ & $\begin{array}{c}\text { Short } \\
\text { w/for } \\
(2)\end{array}$ \\
\hline 1998-I & 0,58494 & 0,954 \\
II & 0,571 & 0,940 \\
III & 0,473 & 0,872 \\
IV & 0,5512 & 0,880 \\
I999-I & 0,1160 & 0,380 \\
II & 0,1145 & 0,219 \\
III & 0,1182 & 0,147 \\
IV & 0,1173 & 0,194 \\
2000-I & 0,1068 & 0,185 \\
II & 0,1070 & 0,170 \\
III & 0,1070 & 0,170 \\
IV & 0,1060 & 0,197 \\
B & 0,1055 & 0,190 \\
2001-I & 0,0904 & 0,163 \\
II & 0,0859 & 0,146 \\
III & 0,085 & 0,136 \\
IV & 0,078 & 0,105 \\
\hline & &
\end{tabular}

In the simulation part of the paper, the chosen specifications were number (2) (the short sample linear model with forward looking expectations), which is the most standard, but with the long run rigidity in nominal variables as explained below and also number (4), which has the coefficient for the cross term output gap and exchange rate difference with the expected sign. 


\section{A SIMPLE MODEL WITH TRADE BALANCE}

In order to test for the role of the exchange rate as part of the monetary policy rule, we have to present a complete small inflation-targeting model, which includes an equilibrium condition for the external sector in order to define the exchange rate behavior.

The IS equation is very simple. The aggregate demand only depends on itself with a lag, on the lagged real interest rate and on the real exchange rate.

$$
h_{t+1}=a_{10}+a_{11} h_{t}+a_{12}\left(i_{t}-\pi_{t}\right)+a_{13} \theta_{t}+u_{t}
$$

Where $h$ is the $\log$ of the output gap based on a linear trend, $\theta$ is the real exchange rate, $i$ is Selic rate, $\pi$ is consumer price inflation, and $u$ is the demand disturbance.

The Phillips equation is compatible with any open economy Keynesian model with the restriction of long-term nominal neutrality, which means a vertical Phillips equation in the long run. The econometric estimations in the previous section have not included this restriction in order to be comparable with Goldfajn and Werlang (2000). This restriction implies that the coefficients associated with the nominal variables should sum up to 1 . Specifications (2) and (4) of the previous sections are used with the restriction explained above.

$$
\pi_{t}=a_{21} \pi_{t-1}+E_{t}\left[\left(1-a_{21}-a_{22}\right) \pi_{t+1}\right]+a_{22}\left(e_{t}-e_{t-1}\right)+a_{24} h_{t-1}+\varepsilon_{t}
$$

Where $\varepsilon$ is the aggregate supply disturbance and $\left(e_{t}-e_{t-1}\right)$ is the first difference of nominal exchange rate.

In the appendix one can see the calibrated coefficients for IS equation and for the Phillips curve.

The next equation is a Taylor Rule. However, following Ball (2000) and Mishkin (2000), we add an exchange rate term to the standard rule. In his paper Policy Rules and External Shocks Ball reckons that policy rules used in closed economies do not fit well for countries that are more sensitive to ex- 
ternal shocks. In open economies, such rules should be modified to include the exchange rate. Hence, he suggested a modification in the Taylor rule so that the exchange rate is also included as an instrument in the left-hand side, which is called the Monetary Condition Index (MCI). He presents a very simplified model similar in many ways with the model that is presented in this section.

Ball (2000) in page 12 obtained the following result that we will test for the Brazilian case:

"When there is a shock to net foreign investment, an MCI target keeps output more stable than an interest-rate target."

The rationale is that when the interest rate is kept constant there is a major devaluation of the exchange rate, which raises aggregate output. On the other hand, when the MCI is held constant, there is a smaller devaluation associated with a rise in the interest rate, with opposite effects on aggregate output that might be held constant.

Ball concludes that "stability is also enbanced by including the exchange rate in policy reaction function."

In his recent paper Mishkin (2000):

"also reinforces the importance of the exchange rate in inflation targeting for emerging countries.”

The author suggests:

"that emerging market countries cannot afford to ignore the exchange rate when conducting monetary policy under inflation targeting, but the role they ascribe to is should be clearly subordinated to the inflation objective. It also suggests that inflation targeting in partially dollarized economies may not be viable unless there are stringent prudential regulations on, and strict supervision of, financial institutions that ensure 
that the system is capable of withstanding exchange rate shocks."

If Central Banks are willing to respond strongly to defend the exchange rate, this might hurt the credibility of the monetary policy as the public perceives that protecting the exchange rate is more important than assuring price stability.

The conclusion of the author is that

"One possible way to avoid this problem is for inflation-targeting central banks in emerging market countries to adopt a transparent policy of smoothing short-run exchange-rate fluctuations that helps mitigate potentially destabilizing effects of abrupt exchange rate changes while making it clear to the public that they will allow exchange rates to reach their market-determined level over longer horizons."

Hence, there are two instruments in order to reduce inflation rate and the output gap. We are considering that an appreciation will reduce inflation and the output gap, so the second term of the left-hand side of the equation is negative. We are also considering in the rule the first difference of the nominal exchange rate instead of its level. Therefore, the augmented Taylor rule is:

$$
\omega i_{t}-(1-\omega) e_{t}=a_{30}+a_{31}\left(\pi_{t-1}-\pi_{t-1}^{*}\right)+a_{32} h_{t-1}+a_{33} i_{t-1}
$$

When $\omega$ is set equal to one, it is again a standard Taylor rule.

The determination of exchange rate is based on the UIP with fundamentals, in line with Muinhos, Freitas and Araujo (2000), as stated in equation (6). In order to estimate the exchange rate path, however, it is necessary to anchor the exchange rate at some point in the future. An alternative to achieve this result is to assume that at period $t+K$ the nominal exchange rate will be consistent with a constant current account/GDP ratio. For each period between $t$ and $t+K$, the nominal exchange rate will move according to the interest rate differential corrected by the risk premium, as predicted by the 
UIP hypothesis. Therefore, the following 2 equations determine the exchange rate path:

$$
\begin{aligned}
& E_{t} e_{t+n}=-\sum_{j=n}^{K-1} E_{t}\left(i_{t+j}-i_{t+j}^{*}-x_{t+j}\right)+E_{t} e_{t+K}, \text { for } n<k \\
& E_{t} e_{t+K}=\theta_{t+K}-p_{t+K}^{f}+p_{t+K}
\end{aligned}
$$

where $\theta$ is the expected real exchange rate compatible with a constant current account/GDP ratio in the medium run, and $x_{t}$ is an exogenous risk premium that follows an $\mathrm{AR}(1)$ process.

The equilibrium equation is:

$$
(B S+B C) / y=b
$$

where $B S$ is the balance of services surplus in real terms, $B C$ is the trade balance surplus in real terms $y$ is the real GDP and $b$ is a arbitrary current account/GDP equilibrium ratio, that represents a net capital flow consistent with an equilibrium scenario for the capital account. This ratio $b$ is a source of external shock, representing different international finance liquidity conditions as presented in the simulations. $B S$ is an exogenous variable and $B C$ is determined by:

$$
B C=\sum_{j=1}^{2} \alpha_{j} Q_{j}(y, \theta) P_{j}
$$

Where $P_{j}$ is the price index vector for exported and imported goods. $Q_{j}$ is the quantitative index for exported and imported goods, which depends on the output gap and the real exchange rate, $\alpha$ s are the weights to transform the indexes in US\$ terms.

All the estimates are done using quarterly data with the sample period initiating in 1980. We will report here only the coefficients for the trade balance.

9 where $e^{v}=\left[\begin{array}{llll}e^{v_{1}} & e^{v_{2}} & \ldots & e^{v_{N}}\end{array}\right]$ with $v=\left[\begin{array}{lllll}v_{1} & v_{2} & \ldots & v_{N}\end{array}\right]$. 
The quantitative index for exports is estimated in level, because we could reject the unit root for the series. The estimated equation for exports including the t-statistics in parentheses is:

$\exp _{t}=\underset{(-4,31)}{2,566}+\underset{(8,85)}{0,61} \exp _{t-1}+\underset{(5,63)}{0,29} y_{t}^{*}+\underset{(3,56)}{0,26 \theta_{t}}+$ seasonaldummies $-\underset{(-6,13)}{0,48} d$ Cruzado

Where $y_{t}^{*}$ is the world GDP measure as the log of the world's import quantitative index. The sample for the above equation comprises the 1991 to 2000 period. We used instrumental variables to avoid correlation between the contemporaneous regressors and the residual. All other information is in the Annex.

When a unit root test is conducted in the import quantitative quantum index, the null of unit root cannot be rejected. However it is clear that a structural break happened in the early 1990', due to the opening of the economy in the period, which eliminated the ban on some imports and reducing the average import tariff s. If a dummy variable is inserted in the unit root test, one can reject the unit root hypothesis. Hence the estimated equation for imports is:

$i m p_{t}=\underset{(0,56)}{0.34}+\underset{(13,72)}{0.78} i m p_{t-1}+0 \underset{(2,13)}{0.23} y_{t}-\underset{(-2,81)}{0.16} \theta_{t}+$ seasonaldu mmies $+\underset{(3.48)}{0.30} d$ Cruzado $+\underset{2.85}{0.22} d 1993$

where d1993 is a dummy that is zero until $1993: 3,0.5$ from then to 1994:3 and one afterwards.

\section{SIMULATION RESULTS}

For the simulation, the two specifications of the Phillips curve were used: number (2) and number (4). Both are with a forward-looking term for inflation.

For the Phillips equation (2), two types of shocks were tested. The first is to the current account. Three scenarios were considered. The basic one supposes that at the end of 2005 the current account deficit/GDP ratio (net capital flow) will reach 2 . The worst scenario anticipates a tightening in the 
international environment, with only a current account deficit of $1 \%$ of GDP being sustainable.

Figure 1 shows the two scenarios for net capital flow. When there is a tightening in the financial markets, the exchange rate has to be devalued to assure a correction in the trade balance to offset the capital shock. This movement increases inflation and so the interest rate reacts to correct the deviation of inflation from the target. For the same external shock, the non linear Phillips curve brings about very similar results. The only slight difference is the higher level of the output gap in the end of the simulation period for the non-linear Phillips curve. The solid result is the depreciation of the nominal exchange rate in $\mathrm{R} \$ 0,35$ per dolar when the equilibrium capital flow shrunk from $2 \%$ to $1 \%$ of the GDP. Under the shock, the non-linear presents a bit smaller nominal exchange and interest rate.

FIGURE 1 - THE TWO PHILLIPS CURVE WITH AND WITHOUT EXTERNAL SHOCK

\section{INFLATION}

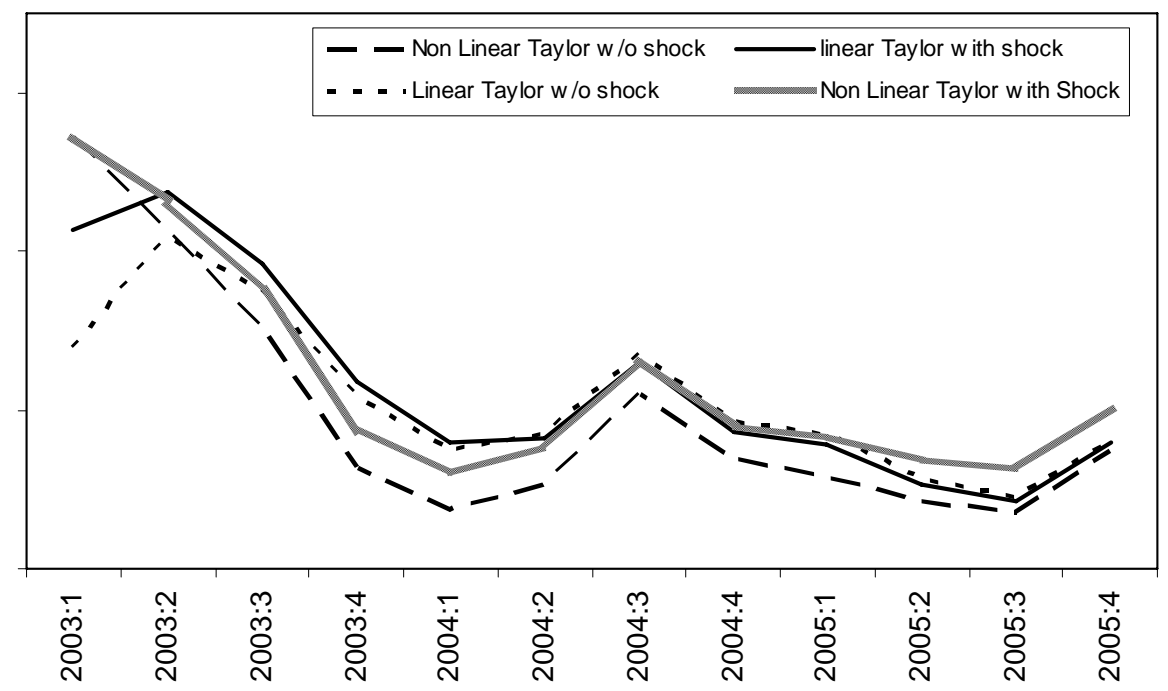




\section{OUTPUT GAP}

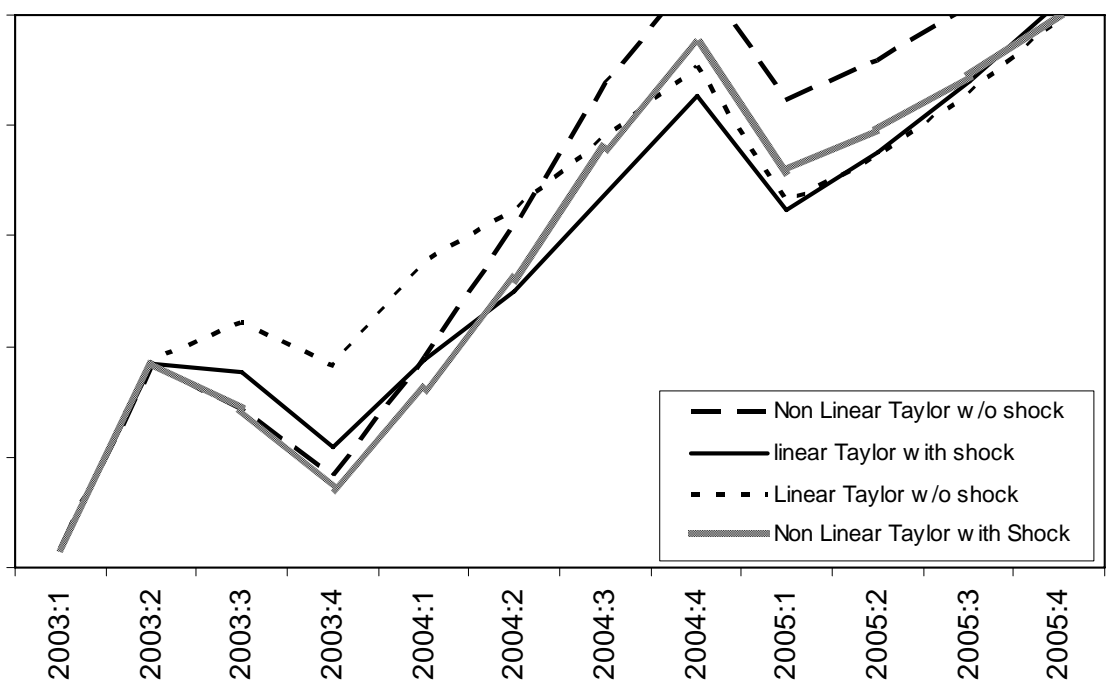

NOMINAL EXCHANGE RATE

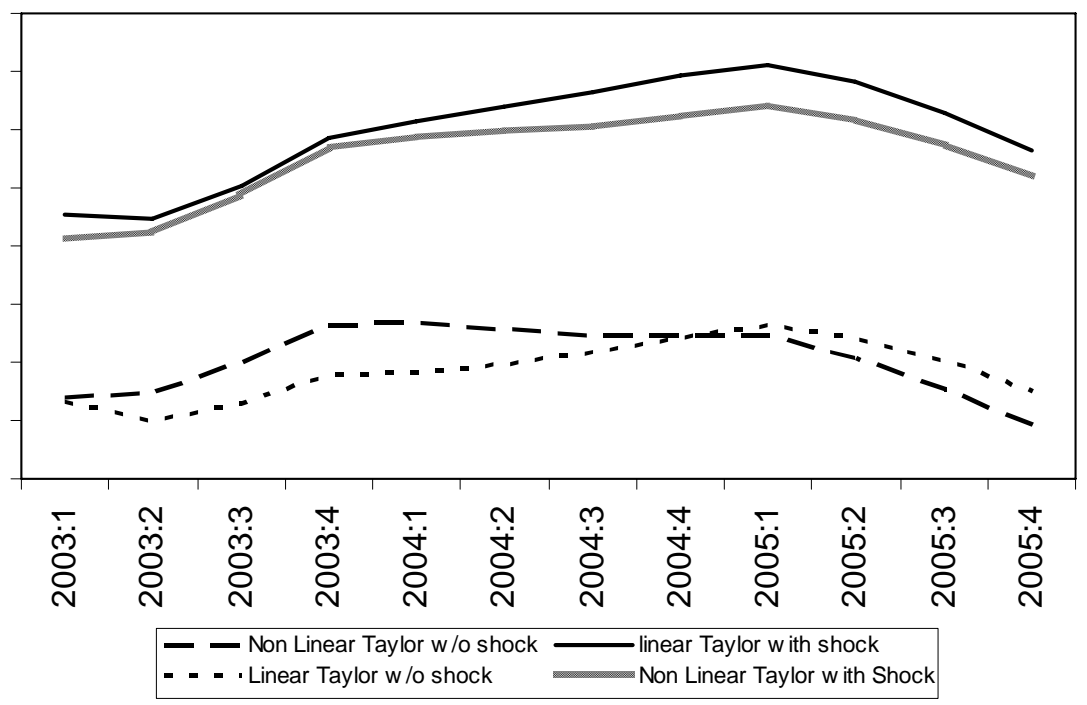


NOMINAL INTEREST RATE

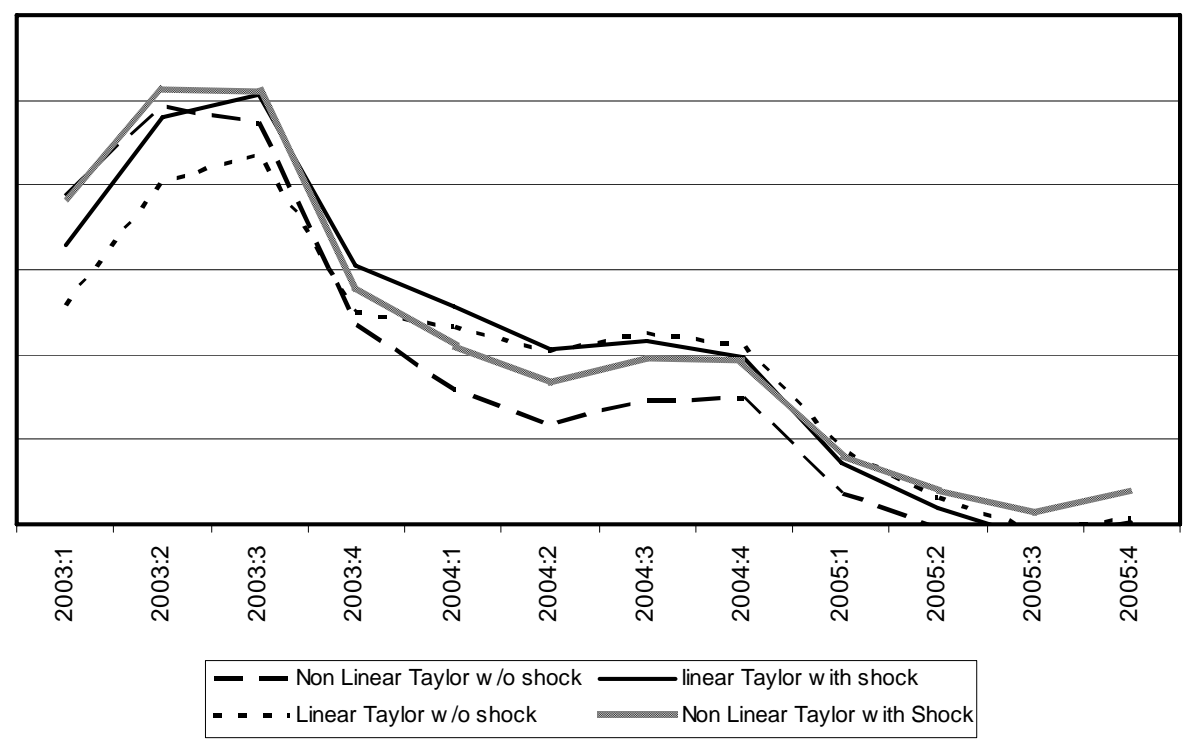

Figure 2 shows different parameterizations of the weight of the exchange rate in the Taylor rule. This weight is not result of any optimization process. It is in line with this kind of rule, when Taylor and Monetary Condition Index (MCI) always assume an ad-hoc value. The benchmark is a scenario with no external shocks nor any value for the exchange rate in the Taylor Rule. The first alternative is to set the parameter $\omega$ at 0.85 , meaning that the exchange rate is also used as a monetary policy instrument. In the second alternative, $\omega$ is equal to 0.7. As one can see in Figure 2, the third option brought about an increase of the volatility of the relevant variables. 
FIGURE 2 - THE LINEAR PHILLIPS CURVE WITH DIFFERENT WEIGHTS ON EXCHANGE RATE

INFLATION

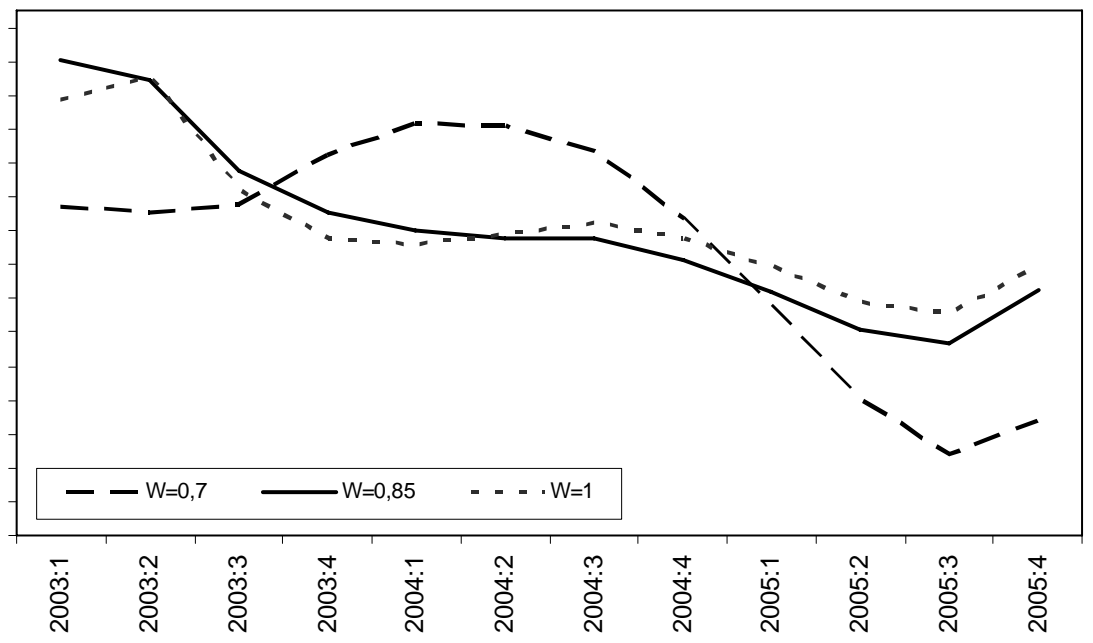

OUTPUT GAP

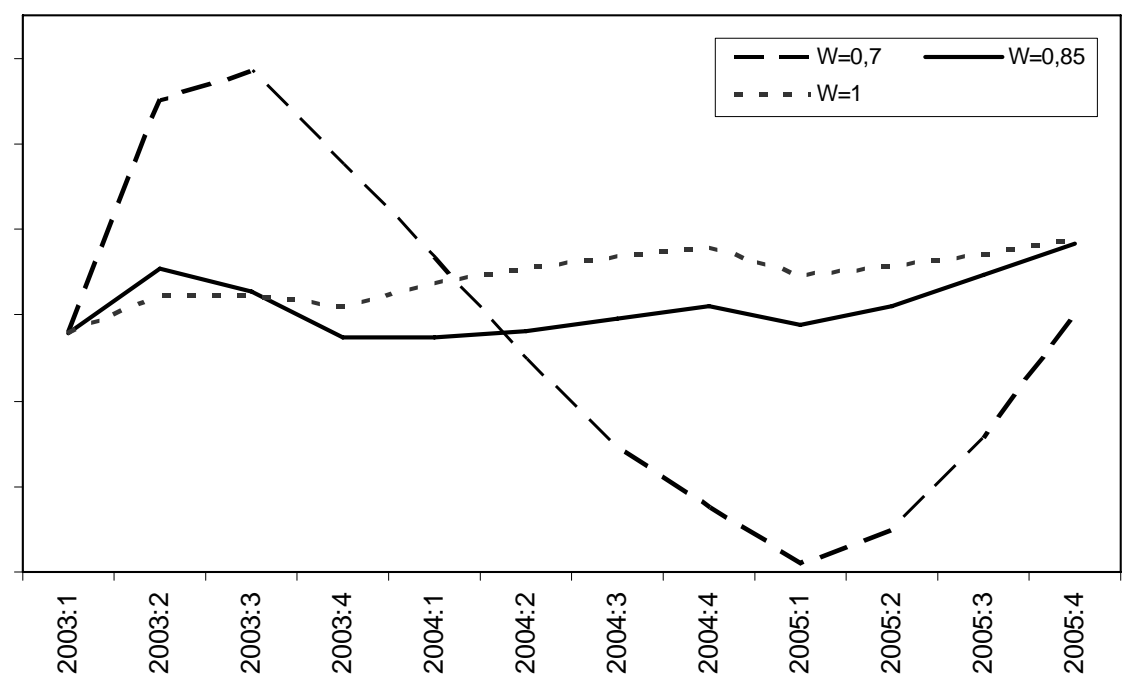


NOMINAL EXCHANGE RATE

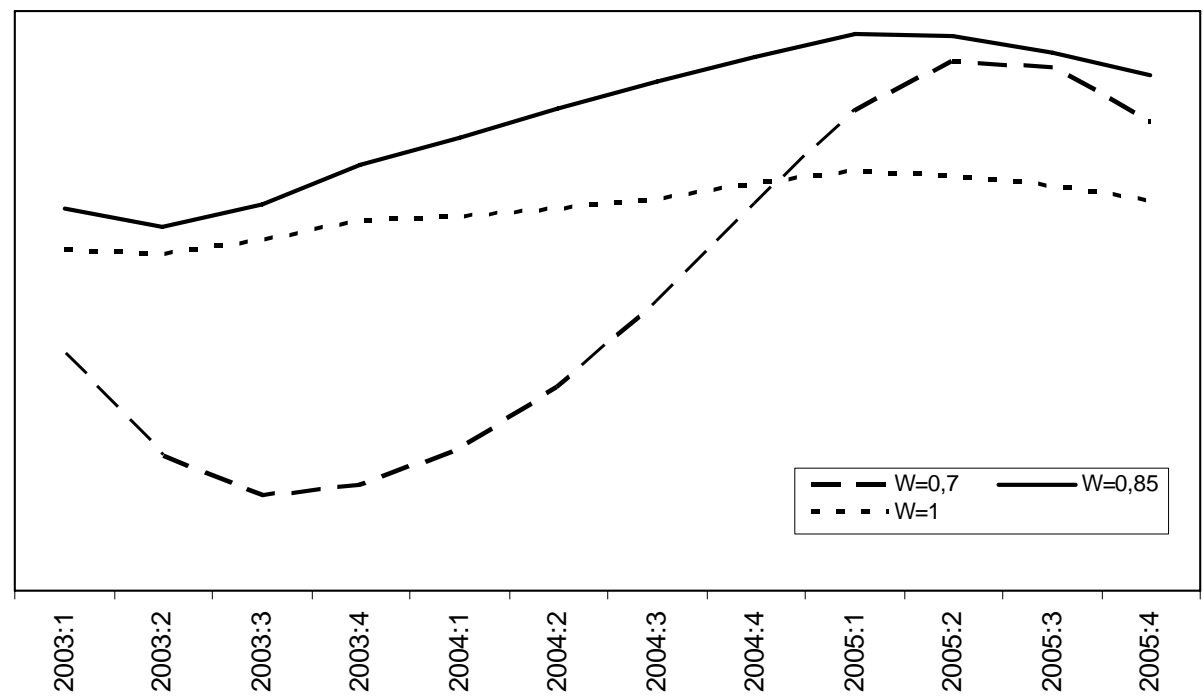

NOMINAL INTEREST RATE

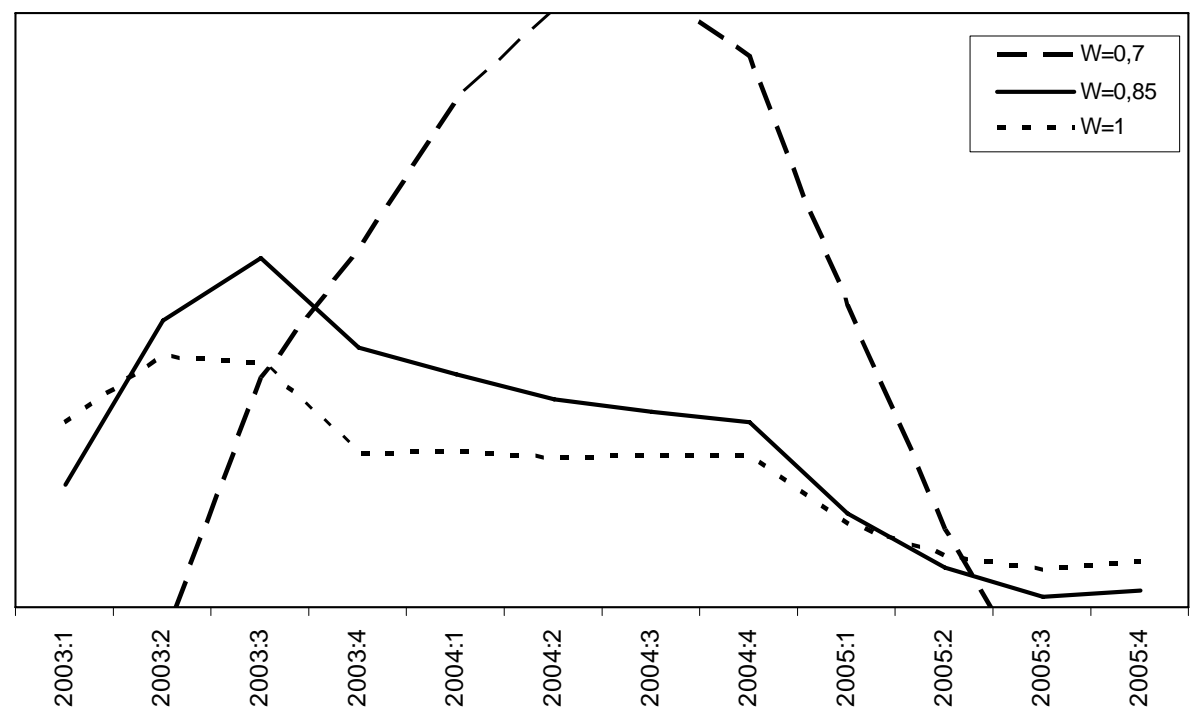

Figure 3 presents the two Taylor rule alternatives when the economy is subject to an external constraint (net capital flow bellow $1 \%$ of GDP). In the first alternative no weight is given to the exchange rate. After the shock, the exchange rate and the inflation rate increase less than when the exchange rate is taken into account as a monetary instrument. But the sharp increase 
in the interest rate results in larger output volatility. The intuition from Ball (2000) does not work in the case of Brazil, because the coefficient for exchange rate in the IS curve is very small. So the exchange rate's devaluation impact on GDP does not offset the impact of the higher interest rate.

FIGURE 3 - TAYLOR RULE, MCI AND EXTERNAL SHOCK (LINEAR)

INFLATION

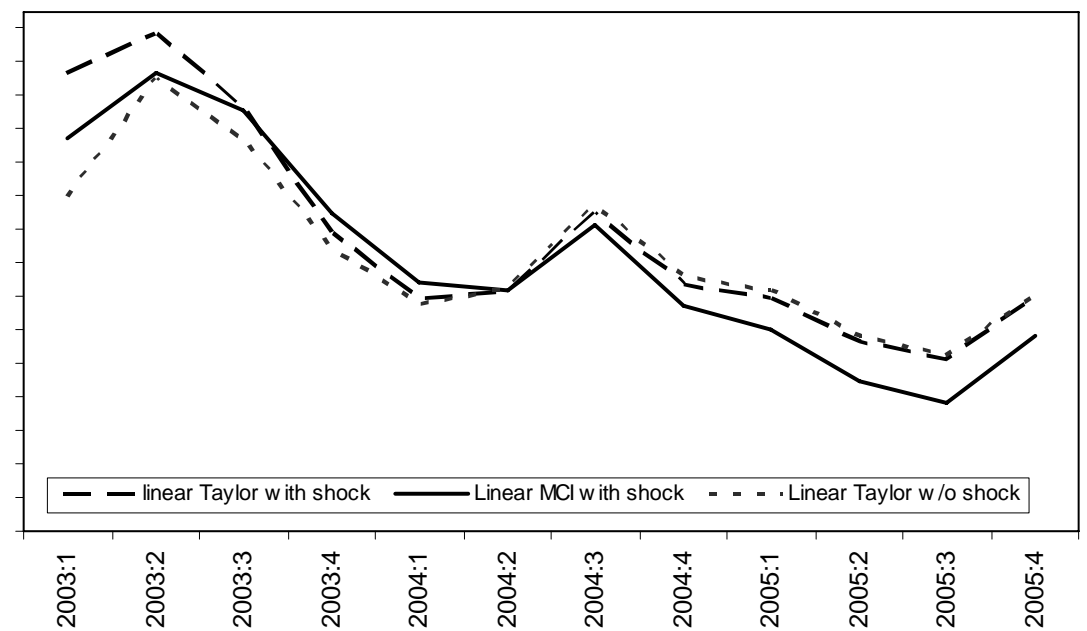

OUTPUT GAP

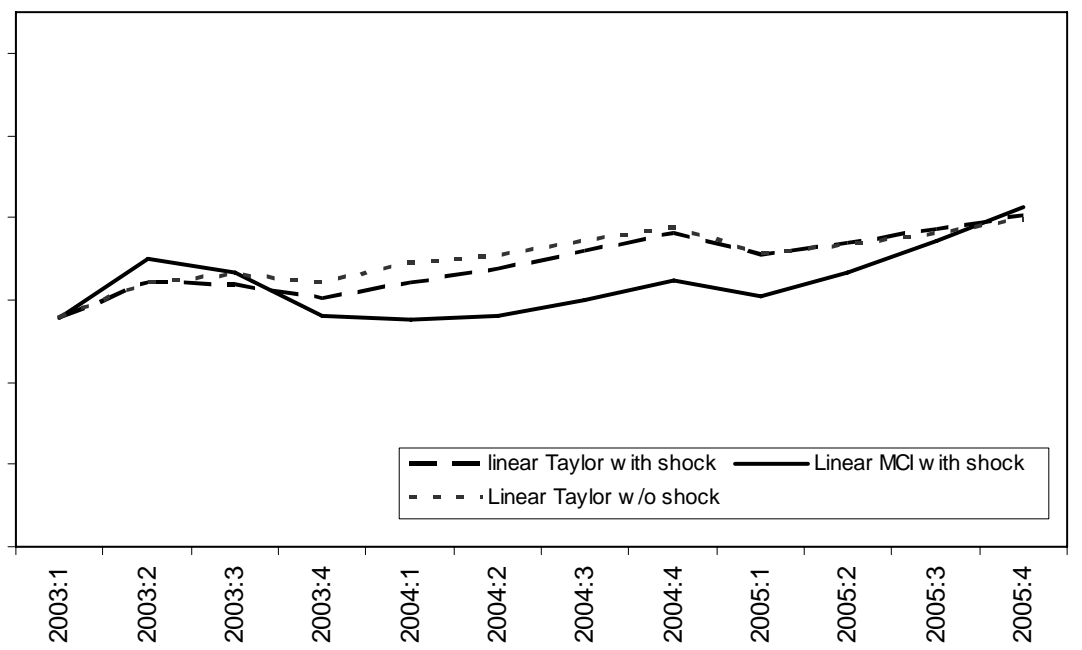


NOMINAL EXCHANGE RATE

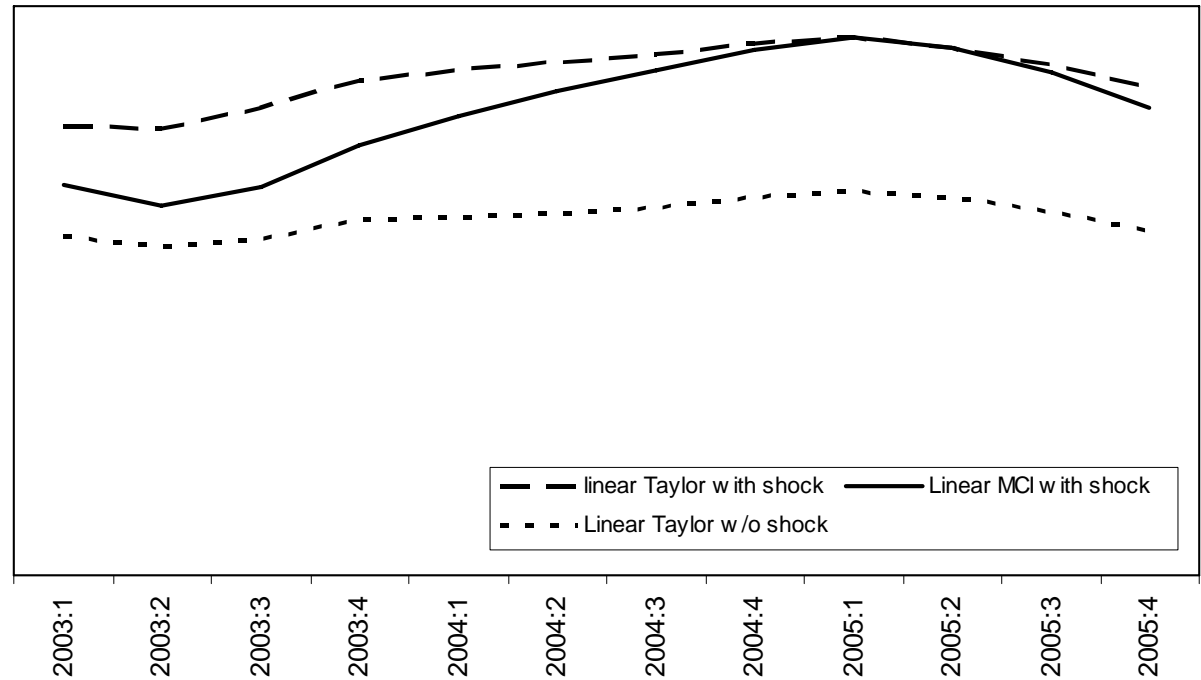

NOMINAL INTEREST RATE

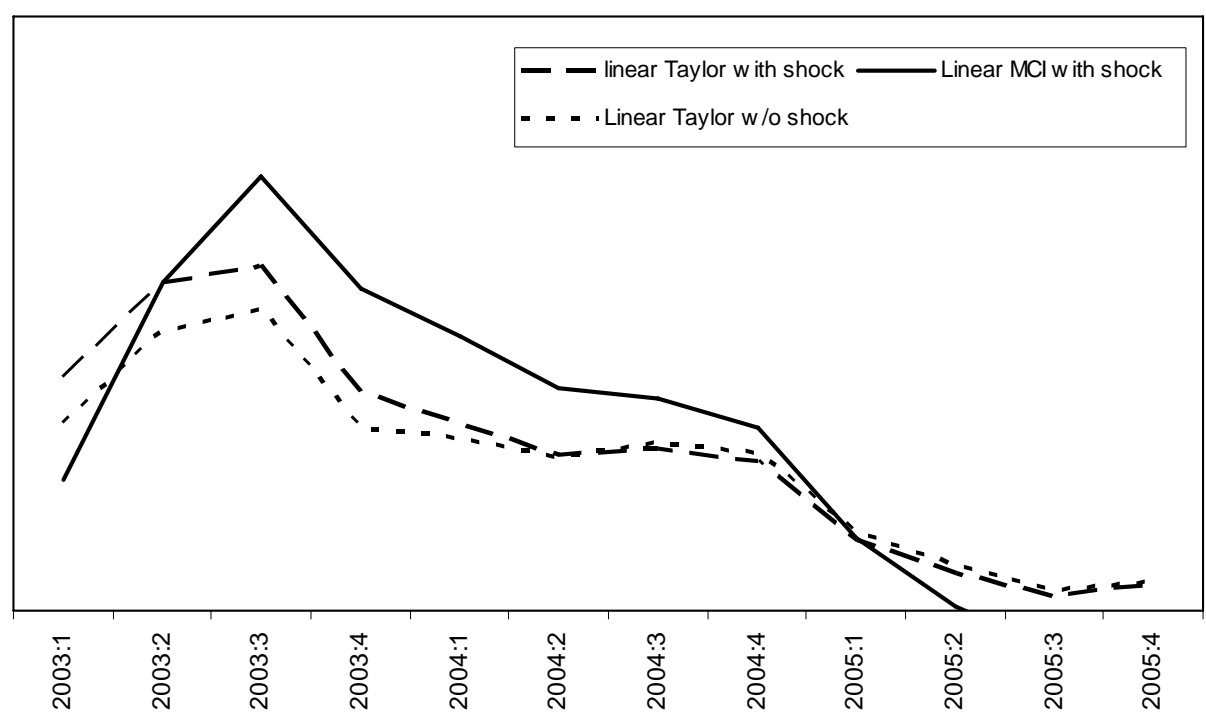

Figure 4 shows how the standard Taylor Rule and the MCI index works for the non-linear Phillips curve under an external shock. The behavior shows the same pattern as in the linear version (Figure3), with a sharper increase 
in the interest rate and a smoother exchange rate with the MCI rule but with a greater sacrifice ratio.

FIGURE 4 - TAYLOR RULE, MCI AND EXTERNAL SHOCK (NON LINEAR)

\section{INFLATION}

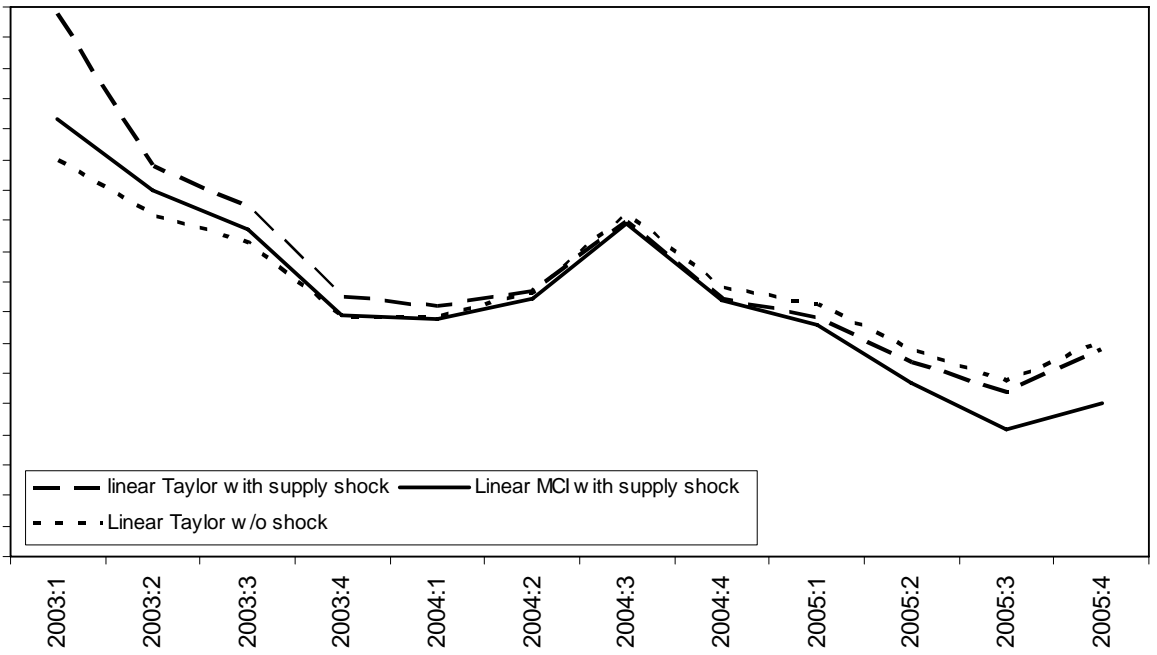

\section{OUTPUT GAP}

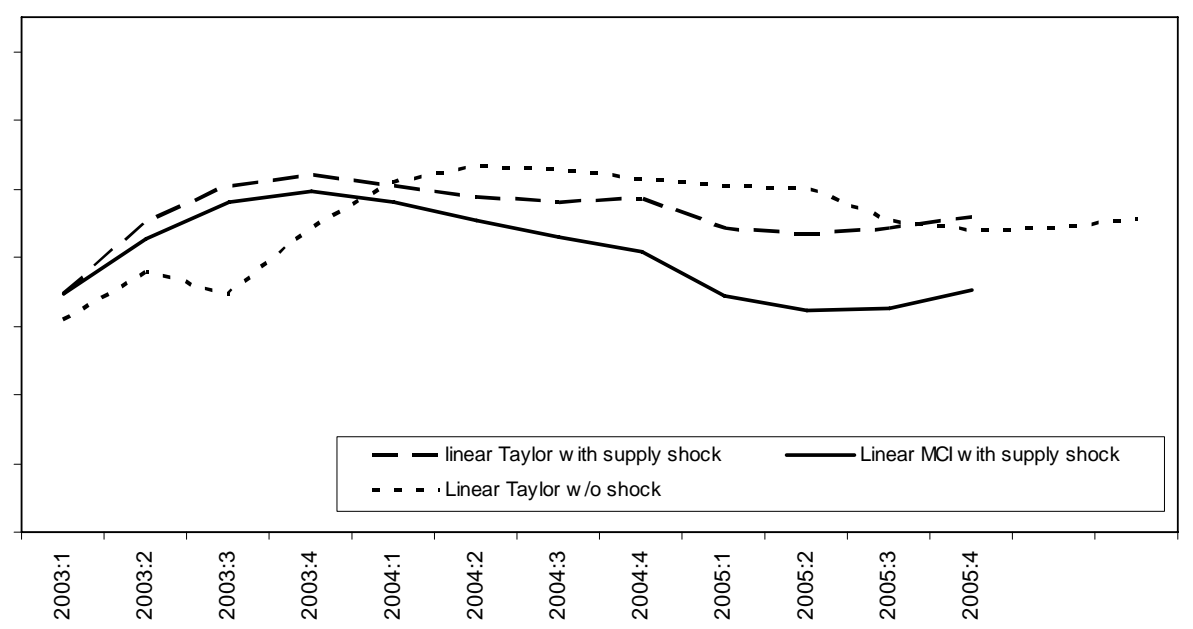


NOMINAL EXCHANGE RATE

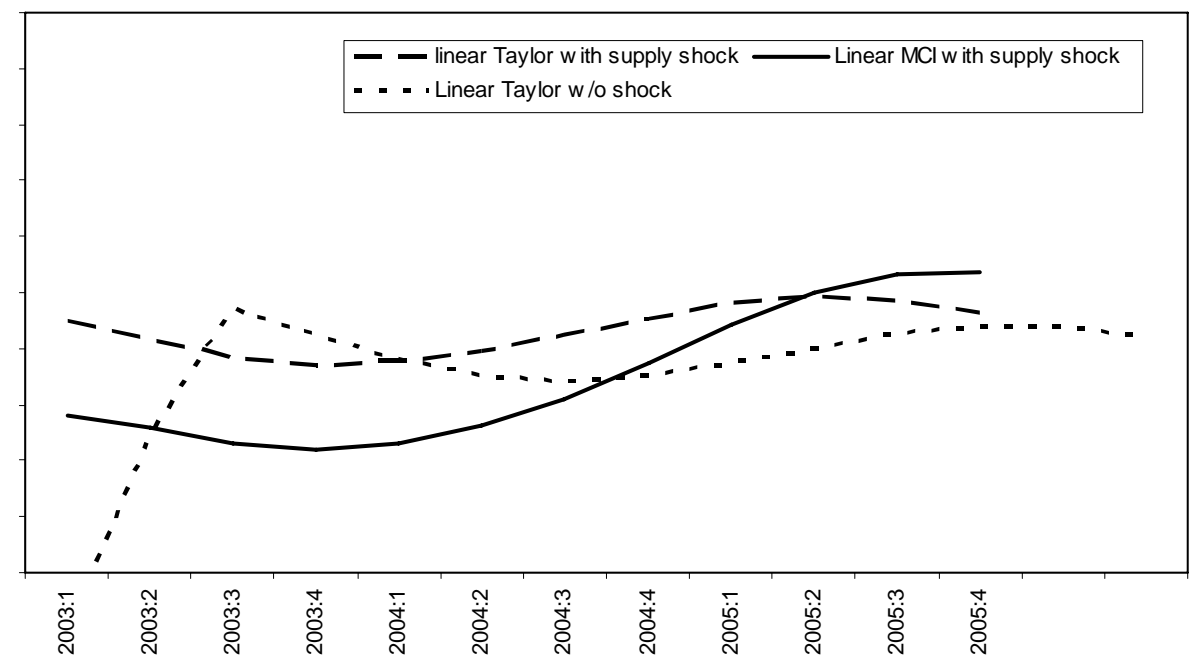

NOMINAL INTEREST RATE

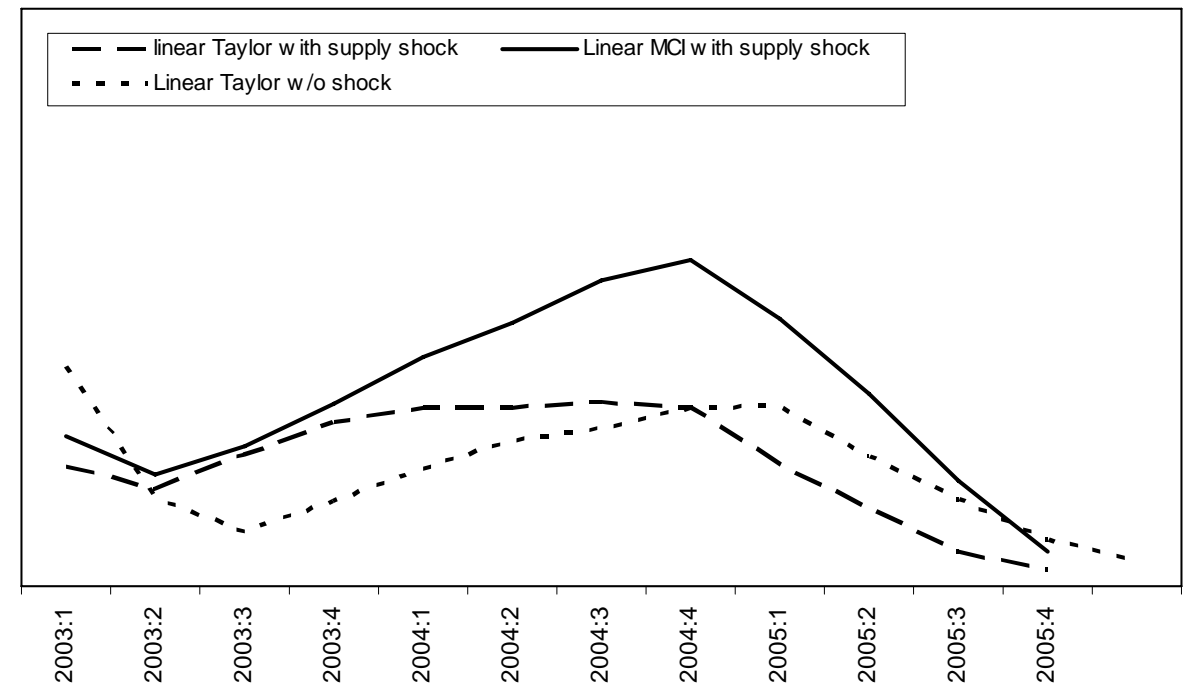

One can conclude that when the model is hit by an external shock, a pure Taylor rule will allow a major depreciation and according to Ball, it would increase output, but our model presented more stable output. When a MCI is considered the nominal exchange rate did not depreciate as much but the 
model suggested a decrease in output in opposite to Ball's suggestion of a more stable output.

\section{FINAL REMARKS}

Even considering that exchange rate devaluations in emerging economies may cause high pass-through, financial instability and sluggish output recoveries, these stylized facts have not been observed in Brazil in the episode of the switching for a floating exchange rate in 1999, at least as the high pass-through. These results presented for Brazil show a smaller passthrough than found by for other American countries. In 2002, after a new wave of exchange rate devaluation, the pass-through seemed to be slighter higher, due to the higher initial inflation, less recessive economy activity and an already depreciated exchange rate. These results in 2002 are again in line with Goldfajn and Werlang (2000).

The non-linear Phillips curve with no forward-looking term does not fit well for the Brazilian data, but the other two with the forward term present consistent results for the two different sample periods. The linear models bring about a major break in the 1999 floating episode what would suggest caution by using those for forecasting purpose.

In addition to the fact that some degree of exchange rate devaluation may be well absorbed in the Brazilian economy due to the low pass-through, the introduction of the exchange rate as a monetary policy instrument does not produce lower volatility results in response to external or supply shocks, regardless of using the linear or non-linear specification of the Phillips curve.

The feature of the UIP with fundamentals seems a feasible explanation for the devaluation in the second half of 2002. A confidence crises cause a reduction in the capital flow towards Brazil, what means a new current account GDP equilibrium ratio, which implies depreciation in the domestic currency. 
In the fixed exchange rate regime the entire burden of the shock adjustment is borne by the interest rate. Increasing the volatility of the exchange rate in order to decrease the volatility of the interest rate may be better for the economy.

Why not allow the exchange rate volatility?

- fear of inflation - the results in this paper showed us that Brazilian passthrough has been very low;

- fear of floating - the recent experience proved to us that the balance sheet effects were not so large that they could be safety absorbed in 1999 ;

- fear of output volatility - the effect of real exchange rate on IS curve was also very small.

The simulations results show that it is better to use a Taylor rule allowing the exchange rate to float using the interest rate only to control inflation.

\section{REFERENCES}

BALL, Laurence. Policy rules and external shocks. NBER Working Paper Series 7910, Cambridge Ma, 2000.

BOGDANSKI, Joel; TOMBINI, Alexandre; WERLANG, Sergio R. C. Implementing inflationtargeting in Brazil. Banco Central do Brasil Working Paper Series n. 1, Brasília,

CALVO; REINHART. Fear of floating. University of Maryland, 2000. Mimeografado.

GOLDFAJN, Ilan; OLIVARES, Gino. Can flexible exchange rates still "work" in financially open economies. G-24 Discussion Paper N. 8, 2001.

GOLDFAJN, Ilan; WERLANG, Sergio R.C. The pass-through from depreciation to inflation: a panel study. Banco Central do Brasil Working Paper Series n. 5, Brasília, 2000.

HAUSSMANN, Ricardo; PANIZZA, Ugo; STEIN Ernesto. Why do countries float the way they float. Working Paper n. 418, InterAmerican Development Bank, 1999. 
MISHKIN, Frederic. Inflation targeting in emerging market countries. NBER Working Paper Series 7618, Cambridge Ma, 2000.

MUINHOS, Marcelo; FREITAS, Paulo; ARAÚJO, Fabio. Uncovered interest parity with fundamentals: a Brazilian exchange rate forecast model. Banco Central do Brasil Working Paper Series n. 19, Brasília, 2000 .

RODRICK, Dani. Exchange rate regimes and institutional arrangements in the shadow of capital flows. Kennedy School of Government, Harvard University, 2000. Mimeografado.

\section{APPENDIX}

PARAMETER OF THE PHILLIPS CURVE

\begin{tabular}{lrr}
\hline Phillips & \multicolumn{1}{l}{ Linear } & \multicolumn{1}{l}{ Non-Linear } \\
\hline Constant & & \\
Pass-Though & 0.091181 & \\
Real Exchange & & 0.02703 \\
Output Gap & 0.17 & 0.219254 \\
Pi(t-1) & 0.359419 & 0.308815 \\
Pi(t-2) & 0.0924 & \\
Pi(t+1) & 0.457 & 0.496774 \\
Pass-Though Constant & & 0.2652 \\
Real Exchange*Pass-Though. & & -0.666067 \\
Output Gap*Pass-Though & & -0.009858 \\
\hline
\end{tabular}

PARAMETER OF THE IS CURVE

\begin{tabular}{lr}
\hline IS Curve & Coefficients \\
\hline Constant & 0.0111 \\
Output Gap(t-1) & 0.62 \\
Real Interest Rate & -0.45 \\
Real Exchange Rate & 0 \\
Fiscal Variable & 0.018 \\
\hline
\end{tabular}




\section{PARAMETER OF THE TAYLOR RULE}

\begin{tabular}{lc}
\hline Taylor Rule & Weights \\
\hline Inflation & 1.5 \\
Output Gap & 0.5 \\
Interest t-1 & 0.6 \\
$1-\omega(\mathrm{MCl}$ Index) & 1 \\
\hline
\end{tabular}

The author would like to thank without implications Gil Riella for excellent contributions in running the simulations, Ilan Goldfajn, Pedro Miranda, Edwin Truman, Joaquim Andrade, Maria Beatriz Costa, Thais Porto Ferreira and José Pedro Fachada for reading early drafts of this paper. The views expressed in this work are those of the author and not reflect those of the Banco Central do Brasil or its members.

Email and address: marcelo.kfoury@bcb.gov.br. Research Department $9^{\circ}$ floor SBS Quadra 3 Bl.B 70074-900 Brasilia DF- Brazil Telefone 61 4142748 Fax 612260767

(Recebido em setembro de 2002. Aceito para publicação em março de 2004).

Est. econ., São Paulo, 34(2): 269-296, abr-jun 2004 